\title{
PROMOSI JABATAN ESELON IV PADA BADAN KEPEGAWAIAN PENDIDIKAN DAN PELATIHAN KABUPATEN GORONTALO
}

\author{
Kasmudin H. Sabi ${ }^{1}$ \& Lisda Van Gobel ${ }^{2}$ \\ STIA Bina Taruna Gorontalo \\ bukujurnalstia@binataruna.ac.id ${ }^{1}$ \& lisdavangobel69@gmail.com²
}

\begin{abstract}
ABSTRAK
Penelitian ini bertujuan untuk mengetahui promosi jabatan eselon IV pada Badan Kepegawaian Pendidikan dan Pelatihan Kabupaten Gorontalo. Metode penelitian menggunakan jenis deskriptif pendekatan kualitatif. Teknik pengumpulan data dilakukan melalui wawancara mendalam kepada sejumlah informan, observasi dan pencatatan data sekunder yang berkaitan dengan permasalahan penelitian.
\end{abstract}

Hasil penelitian menyimpulkan bahwa, pelaksanaan promosi jabatan eselon IV berdasarkan kemampuan belum menjadi syarat mutlak. Hal ini terlihat dari pelaksanaan promosi jabatan di Badan Kepegawaian Pendidikan dan Pelatihan Kabupaten Gorontalo yang lebih banyak ditentukan oleh faktor kedekatan dan mengabaikan aspek kemampuan. Pelaksanaan promosi jabatan eselon IV berdasarkan prestasi kerja belum menjadi syarat mutlak. Hal ini terlihat dari Daftar Penilaian Pelaksanaan Pekerjaan (DP3) pegawai yang kurang obyektif dan terdapat beberapa pegawai yang dipromosikan pada tingkat eselon IV tanpa prestasi kerja yang baik. Pelaksanaan promosi jabatan eselon IV berdasarkan senioritas belum menjadi syarat mutlak. Hal ini terlihat dari banyak pejabat eselon IV yang masih muda dan banyak juga pegawai yang bekerja lama tetapi belum memiliki eselon. Pelaksanaan promosi jabatan berdasarkan aspek pendidikan belum terpenuhi. Hal ini terlihat dari pelaksanaan promosi jabatan yang lebih mempertimbangkan pendidikan dari aspek jenjang ataupun kualifikasinya saja tetapi tidak mempertimbangkan dari aspek spesifikasi keilmuannya dengan bidang pekerjaan yang akan digelutinya.

Disarankan, perlunya Badan Kepegawaian Pendidikan dan Pelatihan Kabupaten Gorontalo mengedepankan aspek kemampuan, aspek prestasi kerja, aspek senioritas, dan aspek pendidikan.

Kata Kunci: Promosi; Jabatan; Eselon

\section{PENDAHULUAN}

Dalam rangka untuk mencapai tujuan nasional diperlukan pegawai negeri yang merupakan unsur aparatur negara yang bertugas secara adil dan merata, menjaga kesatuan dan persatuan bangsa dengan penuh kesetiaan kepada Pancasila dan 
PUBLIK: Jurnal Manajemen Sumber Daya Manusia, Administrasi dan Pelayanan Publik Sekolah Tinggi Ilmu Administrasi Bina Taruna Gorontalo Volume VI Nomor 2 Desember 2019

Undang-Undang Dasar 1945. Guna mencapai tujuan tersebut diperlukan pegawai negeri yang mempunyai kemampuan melaksanakan tugas secara profesional dan bertanggung jawab dalam menyelenggarakan tugas pemerintah dan pembangunan. Untuk mendapatkan pegawai negeri yang seperti itu, maka diperlukan usahausaha yang memicu kinerja pegawai negeri.

Ada beberapa hal di dalam manajemen kepegawaian yang digunakan sebagai pemicu semangat kerja pegawai yang akan menghasilkan kinerja yang baik juga. Yang pertama, adalah dengan sistem penggajian yang berfungsi sebagai balas jasa atau penghargaan atas prestasi kerja serta untuk memenuhi kebutuhan hidup bersama keluarganya secara layak yang bertujuan agar ia dapat memusatkan perhatian dan kegiatannya untuk melaksanakan tugas yang dipercayakan kepadanya. Cara yang kedua, adalah dengan ditegakkannya suatu peraturan disiplin pegawai negeri sipil untuk mengontrol perilaku mereka agar selalu melaksanakan segala tugas dan tanggung jawabnya dengan baik dan terarah.

Cara lainnya adalah dengan menggunakan sistem kenaikan pangkat atau promosi yang diberikan kepada mereka yang telah menunjukkan prestasi kerja yang tinggi. Di dalam Peraturan Pemerintah No 99 Tahun 2000 tentang Kenaikan Pangkat
Pegawai Negeri Sipil disebutkan bahwa pangkat bagi pegawai negeri merupakan kedudukan yang menunjukkan tingkat seorang pegawai negeri sipil dalam rangkaian susunan kepegawaian dan digunakan sebagai dasar penggajian.

Di samping itu, ada pula promosi jabatan yang dalam hal ini merupakan penghargaan yang diberikan atas pengabdian pegawai negeri sipil yang bersangkutan terhadap negara. Pada dasarnya kenaikan pangkat yang objektif berkaitan erat dengan pendidikan atau latihan. Di samping itu, promosi atau kenaikan pangkat berhubungan pula dengan penghasilan. Promosi atau kenaikan pangkat adalah sesuatu yang pada umumnya diidamidamkan oleh masing-masing pegawai, sebab dengan demikian ia memiliki hak-hak dan kekuasaan yang lebih besar dari sebelumnya, dan berarti menaikkan penghasilannya.

Promosi jabatan merupakan penghargaan kepada pegawai negeri sipil yang dengan tekun, penuh pengabdian melaksanakan tugas yang dibebankan kepadanya. Karena kenaikan pangkat adalah penghargaan kepada pegawai negeri sipil yang telah mengabdi dengan tekun di dalam melaksanakan tugas sehari-hari, maka sudah sepantasnya diberikan promosi jabatan kepadanya. Sudah seharusnya atasan memperhatikan nasib Pegawai Negeri Sipil yang menjadi bawahannya, sebab promosi jabatan adalah satu-satunya harapan untuk 
PUBLIK: Jurnal Manajemen Sumber Daya Manusia, Administrasi dan Pelayanan Publik Sekolah Tinggi Ilmu Administrasi Bina Taruna Gorontalo Volume VI Nomor 2 Desember 2019

menaikkan gaji dalam situasi promosi jabatan sudah tidak memungkinkan lagi.

Tidak sulit membayangkan bahwa setiap pegawai di manapun selalu mendambakan kemajuan dalam kehidupan kekaryaannya, artinya setiap orang ingin meniti karier sedemikian rupa sehingga selama masa aktifnya berkarya, ia menduduki jabatan dan pangkat yang lebih tinggi yang berarti memikul tanggung jawab yang lebih besar dan penghasilan yang semakin besar pula. Kemajuan dalam karier seseorang tidak terjadi dengan sendirinya. Karier perlu direncanakan dan dikembangkan. Pengalaman banyak menunjukkan bahwa tanggung jawab untuk merencanakan dan mengembangkan karier seorang pegawai berada di pundak tiga pihak, yaitu (1) pegawai yang bersangkutan sendiri, (2) atasan langsung, (3) petugas atau pejabat dari satuan kerja yang mengelola sumber daya manusia dalam organisasi.

Pegawai yang bersangkutan sendiri sangat berkepentingan dalam merencanakan dan mengembangkan kariernya. Perencanaan dan pengembangan kariernya itu merupakan bagian integral dari kehidupan kekaryaan seseorang. Agar meraih kemajuan dalam karier, seorang pegawai tentunya harus menampilkan kemampuan dan produktifitas yang semaksimal mungkin di samping menunjukkan perilaku yang positif dalam berfikir dan bertindak sehingga akan menghasilkan kinerja yang baik pula. Hasil positif yang diharapkan dengan adanya perencanaan karier yang baik antara lain adalah kegairahan bekerja di kalangan para pegawai karena mereka mengetahui bahwa apabila mereka mampu memenuhi persyaratan kepegawaian dengan baik, termasuk prestasi kerja seperti yang diharapkan oleh organisasi, maka karier mereka akan terjamin. Kenaikan pangkat di dalam kepegawaian digunakan sebagai salah satu usaha pemerintah untuk dapat memicu peningkatan prestasi kerja para pegawai negeri sipil yang pada akhirnya akan menghasilkan kinerja pegawai yang baik pula.

Dengan adanya promosi jabatan, maka diharapkan para pegawai tersebut akan berlomba-lomba untuk melaksanakan pekerjaannya dengan sebaik-baiknya dan menghasilkan hasil kerja yang baik pula. Para pegawai tersebut diharapkan memiliki kedisiplinan yang tinggi dan semangat kerja yang tinggi pula dalam melaksanakan tugas-tugas mereka. Karena dengan menghasilkan kinerja yang baik, maka para pegawai itu akan mendapatkan kesempatan untuk diberikan promosi jabatan.

Agar pelaksanaan promosi terbuka memiliki standar dan kualifikasi yang sesuai dengan kebutuhan maka organisasi dipandang perlu menerapkan Peraturan Menteri Pendayagunaan Aparatur Negara dan Reformasi Tentang Tata Cara 
PUBLIK: Jurnal Manajemen Sumber Daya Manusia, Administrasi dan Pelayanan Publik Sekolah Tinggi Ilmu Administrasi Bina Taruna Gorontalo Volume VI Nomor 2 Desember 2019

Pengisian Jabatan Pimpinan Tinggi Secara Terbuka di Lingkungan Instansi Pemerintah (PermenPAN-RB Nomor 13 tahun 2014). Dijelaskan bahwa promosi jabatan pada Instansi Pemerintah Kabupaten/Kota dilakukan secara terbuka dan kompetitif di kalangan PNS dengan memperhatikan syarat kompetensi, kualifikasi, kepangkatan, pendidikan dan latihan, rekam jejak jabatan, dan integritas serta persyaratan lain yang dibutuhkan sesuai dengan ketentuan peraturan perundang-undangan.

Salah satu jenis eselon yang ada pada hirarki jabatan struktural adalah eselon IV yang merupakan hirarki jabatan struktural lapis keempat, terdiri dari 2 jenjang: Eselon IVA dan Eselon IVB. Jenjang pangkat bagi Eselon IV adalah terendah Golongan III/b dan tertinggi Golongan III/d. Ini berarti secara kepangkatan, personelnya berpangkat penata yang sudah cukup berpengalaman. Makna kepangkatannya adalah menjamin mutu. Oleh karenanya di tingkat provinsi, eselon IV dapat dianggap sebagai manajer lini satuan kerja (instansi) yang berfungsi sebagai penanggungjawab kegiatan yang dioperasionalisasikan dari program yang disusun di tingkatan eselon III.

Pelaksanaan promosi jabatan di daerah banyak ditemukan permasalahan dan tidak sesuai dengan peraturan perundang-undangan yang ada termasuk pada pelaksanaan promosi jabatan pada level atas yaitu jabatan eselon IV. Demikian halnya yang terjadi pada Badan Kepegawaian Pendidikan dan Pelatihan Kabupaten Gorontalo. Adapun jumlah eselon IV hingga saat ini yang ada di Badan Kepegawaian Pendidikan dan Pelatihan Kabupaten Gorontalo sebanyak 11 orang.

Hasil pengamatan menunjukkan bahwa promosi jabatan yang dilaksanakan di lingkungan Badan Kepegawaian Pendidikan dan Pelatihan Kabupaten Gorontalo tidak sesuai dengan Peraturan Menteri Pendayagunaan Aparatur Negara dan Reformasi Birokrasi Nomor 13 tahun 2014 tentang tata cara pengisian jabatan pimpinan tinggi secara terbuka di lingkungan instansi pemerintah. Ada beberapa prinsip promosi jabatan yang dilanggar di antaranya: promosi jabatan yang dilakukan oleh Badan Kepegawaian Pendidikan dan Pelatihan Kabupaten Gorontalo kurang mempertimbangkan kompotensi calon pejabat sehingga banyak pejabat yang telah berhasil dipromosikan kurang mengerti akan tugas dan fungsi yang diembannya. Permasalahan berikutnya adalah Badan Kepegawaian Pendidikan dan Pelatihan Kabupaten Gorontalo kurang mempertimbangkan aspek prestasi calon pejabat eselon IV dan lebih mengutamakan orang-orang yang memiliki kedekatan dengan penentu kebijakan meskipun tanpa prestasi. Selanjutnya adalah Badan Kepegawaian Pendidikan dan Pelatihan Kabupaten Gorontalo juga 
PUBLIK: Jurnal Manajemen Sumber Daya Manusia, Administrasi dan Pelayanan Publik Sekolah Tinggi Ilmu Administrasi Bina Taruna Gorontalo Volume VI Nomor 2 Desember 2019

kurang mempertimbangkan prinsip senioritas, dimana orang-orang yang sudah lama mengabdi dan memiliki pengalaman pun kalah bersaing dengan orang-orang baru tetapi memiliki koneksi pada tingkat atas atau penentu kebijakan. Terakhir adalah promosi jabatan yang dilakukan oleh Badan Kepegawaian Pendidikan dan Pelatihan Kabupaten Gorontalo sering mengabaikan faktor pendidikan calon pejabat. Banyak pejabat yang tidak memiliki keterkaitan antara latar belakang pendidikan yang pernah digelutinya pada saat kuliah dengan pekerjaan yang saat ini dihadapinya.

Permasalahan promosi jabatan di lingkungan Badan Kepegawaian Pendidikan dan Pelatihan Kabupaten Gorontalo masih terjadi sampai saat ini, sehingga diperlukan kajian ilmiah yang lebih mendalam dengan melakukan peneltian dengan judul "Promosi jabatan eselon IV pada Badan Kepegawaian Pendidikan dan Pelatihan Kabupaten Gorontalo”.

\section{PERMASALAHAN}

Berdasarkan uraian tersebut di atas, maka rumusan penelitian ini adalah: Bagaimana promosi jabatan eselon IV pada Badan Kepegawaian Pendidikan dan Pelatihan Kabupaten Gorontalo?

\section{TUJUAN DAN MANFAAT PENELITIAN}

\section{Tujuan Penelitian}

Tujuan penelitian ini adalah untuk memperoleh jawaban atas permasalahan pokok penelitian tentang promosi jabatan eselon IV pada Badan Kepegawaian Pendidikan dan Pelatihan Kabupaten Gorontalo.

Manfaat Penelitian

Adapun manfaat penelitian ditinjau dari segi:

Manfaat teoritis bahwa penelitian ini diharapkan dapat mengembangkan keilmuan khususnya ilmu administrasi dan dapat juga dijadikan referensi bagi penelitian lainnya.

Manfaat praktis dari penelitian adalah kiranya dapat menjadi bahan bagi Pemerintah Daerah Kabupaten Gorontalo dalam promosi jabatan eselson IV khususnya pada Badan Kepegawaian Pendidikan dan Pelatihan.

\section{METODE PENELITIAN}

\section{Jenis Penelitian}

Penelitian ini menggunakan jenis deskriptif dengan pendekatan kualitatif. Sedangkan sumber data berasal dari data primer dan sekunder. Teknik pengumpulan data diperoleh melalui observasi, wawancara dan dokumen terkait. Sementara teknis analisis data yang digunakan mengacu pada pendapat Miles dan Huberman 
PUBLIK: Jurnal Manajemen Sumber Daya Manusia, Administrasi dan Pelayanan Publik Sekolah Tinggi Ilmu Administrasi Bina Taruna Gorontalo Volume VI Nomor 2 Desember 2019

(dalam Sugiyono, 2013:337), yang meliputi reduksi data, penyajian data, dan verifikasi data.

\section{Fokus Penelitian}

Salah satu asumsi tentang gejala dalam penelitian kualitatif adalah bahwa segala dari suatu objek itu sifatnya tunggal dan parsial. Dengan demikian berdasarkan gejala tersebut peneliti kualitatif dapat menentukan fokus yang akan diteliti. Adapun yang menjadi fokus penelitian dalam penelitian ini dapat diuraikan sebagai berikut:

\section{Kemampuan}

Kemampuan yang dimaksud dalam penelitian ini adalah kompetensi yang dimiliki oleh Aparatur Sipil Negara untuk dipromosikan dalam jabatan eselon IV

\section{Prestasi Kerja}

Prestasi kerja yang dimaksud dalam pemelitian ini adalah hasil kerja yang dimiliki oleh Aparatur Sipil Negara untuk dipromosikan dalam jabatan eselon IV

\section{Senioritas}

Senioritas yang dimaksud dalam penelitian ini adalah lama kerja dan pengalaman yang dimiliki oleh Aparatur Sipil Negara untuk dipromosikan dalam jabatan eselon IV.

\section{Pendidikan}

Pendidikan yang dimaksud dalam penelitian ini adalah keilmuan yang dimiliki oleh Aparatur Sipil Negara untuk dipromosikan dalam jabatan eselon IV

\section{HASIL PENELITIAN DAN PEMBAHASAN}

Sebagaimana disebutkan di atas bahwa promosi PNS dalam jabatan struktural pejabat struktural mengacu atau berpedoman pada Peraturan Menteri Pendayagunaan Aparatur Negara dan Reformasi Birokrasi Nomor 13 tahun 2014 tentang tata cara pengisian jabatan pimpinan tinggi. Dalam peraturan tersebut disebutkan bahwa jabatan struktural adalah suatu kedudukan yang menunjukkan tugas, tanggung jawab, wewenang, dan hak Pegawai Negeri Sipil dalam rangka memimpin suatu satuan organisasi Negara. Sedangkan tingkatan dari jabatan struktural itu disebut Eselon.

Berikut adalah uraian pembahasan penelitian terkait dengan promosi jabatan eselon IV pada Badan Kepegawaian Pendidikan dan Pelatihan Kabupaten Gorontalo dengan empat fokus penelitian yaitu; kemampuan, prestasi kerja, senioritas dan pendidikan.

Pertama adalah kemampuan. Kemampuan adalah kesanggupan atau kecakapan seorang individu dalam menguasai suatu keahlian dan digunakan untuk mengerjakan beragam tugas dalam suatu pekerjaan. Kemampuan adalah sifat yang dibawa lahir atau dipelajari yang memungkinkan seseorang yang dapat menyelesaikan pekerjaannya, baik secara mental ataupun fisik. Karyawan dalam suatu organisasi, meskipun 
PUBLIK: Jurnal Manajemen Sumber Daya Manusia, Administrasi dan Pelayanan Publik Sekolah Tinggi Ilmu Administrasi Bina Taruna Gorontalo Volume VI Nomor 2 Desember 2019

dimotivasi dengan baik, tetapi tdak semua memiliki kemampuan untuk bekerja dengan baik. Kemampuan dan keterampilan memainkan peranan utama dalam perilaku dan kinerja individu. Keterampilan adalah kecakapan yangberhubungan dengan tugas yang di miliki dan dipergunakan oleh seseorang padawaktu yang tepat.

Kemampuan yang dimaksudkan dalam penelitian ini adalah kompetensi yang dimiliki oleh Aparatur Sipil Negara untuk dipromosikan dalam jabatan eselon IV di lingkungan Badan Kepegawaian Pendidikan dan Pelatihan Kabupaten Gorontalo. Berdasarkan hasil penelitian dan analisis penulis, maka dapat diketahui bahwa pelaksanaan promosi jabatan eselon IV di Badan Kepegawaian Pendidikan dan Pelatihan Kabupaten Gorontalo berdasarkan kemampuan belum menjadi syarat mutlak. Hal ini terlihat dari pelaksanaan promosi jabatan di Badan Kepegawaian Pendidikan dan Pelatihan Kabupaten Gorontalo yang lebih banyak ditentukan oleh faktor kedekatan dan mengabaikan aspek kemampuan.

Kedua adalah prestasi kerja. Prestasi kerja menjadi dasar penting dalam melaksanakan promosi karena dengan prestasi kerja berarti ada kemampuan untuk menjalankan suatu jabatan atau tugas baru yang dibebankan oleh instansi organisasi .Penetapan prestasi kerja sebagai salah satu syarat dalam melakukan suatu promosi akan memotivasi pegawai dalam peningkatan kinerjanya.

Organisasi adalah kumpulan orang yang memiliki kompetensi yang berbeda-beda, yang saling tergantung satu dengan yang lainnya, yang berusaha untuk mewujudkan kepentingan bersama mereka dengan memanfaatkan berbagai sumber daya. Pada dasarnya tujuan bersama yang ingin diwujudkan oleh organisasi adalah mencari keuntungan. Oleh karena itu, diperlukan karyawankaryawan yang mempunyai prestasi kerja yang tinggi. Prestasi adalah catatan tentang hasil-hasil yang diperoleh dari fungsi-fungsi pekerjaan tertentu atau kegiatan tertentu selama kurun waktu tertentu. Prestasi sebagai tingkat kecakapan seseorang pada tugas-tugas yang mencakup pada pekerjaannya. Pengertian tersebut menunjukkan pada bobot kemampuan individu didalam memenuhi ketentuan-ketentuan yang ada di dalam pekerjaannya. Adapun prestasi kerja adalah hasil upaya seseorang yang ditentukan oleh kemampuan karakteristik pribadinya serta persepsi terhadap perannya dalam pekerjaan itu.

Sedangkan prestasi kerja yang dimaksudkan dalam penelitian ini adalah hasil kerja yang dimiliki oleh Aparatur Sipil Negara untuk dipromosikan dalam jabatan eselon IV di lingkungan Badan Kepegawaian Pendidikan dan Pelatihan Kabupaten Gorontalo. Berdasarkan hasil 
PUBLIK: Jurnal Manajemen Sumber Daya Manusia, Administrasi dan Pelayanan Publik Sekolah Tinggi Ilmu Administrasi Bina Taruna Gorontalo Volume VI Nomor 2 Desember 2019

penelitian dan analisis penulis, maka dapat diketahui bahwa pelaksanaan promosi jabatan eselon IV di Badan Kepegawaian Pendidikan dan Pelatihan Kabupaten Gorontalo berdasarkan prestasi kerja belum menjadi syarat mutlak. Hal ini terlihat dari Daftar Penilaian Pelaksanaan Pekerjaan (DP3) pegawai yang kurang obyektif dan terdapat beberapa pegawai yang dipromosikan pada tingkat eselon IV tanpa prestasi kerja yang baik.

Ketiga adalah senioritas. Pengalaman merupakan bentuk pembelajaran yang sangat berharga, memberikan gambaran tentang kejadian masa lalu sekaligus memberikan rujukan untuk memecahkan masalah yang dihadapi saat ini. Pengalaman kerja merupakan salah satu unsur yang menjadikan seorang pegawai berlabel senior atau memiliki fifat senioritas.

Senioritas secara harfiah menurut Kamus Besar Bahasa Indonesia diartikan sebagai keadaan yang lebih tinggi dalam hal pangkat, usia dan pengalaman. Selain itu, dalam senioritas tercermin pula pengertian usia serta pengalaman kerja seseorang. Senioritas di samping dipergunakan sebagai alat pengambilan keputusan untuk tindakan promosi, sering pula dipergunakan sebagai bahan pengambilan keputusan untuk kepentingan penetapan kenaikan gaji berkala. Senioritas dapat dianggap sebagai cara absah untuk melakukan promosi karena senioritas menghindari masalah- masalah dan sikap memihak manajemen yang memberikan kepada karyawan yang difavoritkan kesempatan pertama untuk promosi..

Sedangkan yang dimaksudkan dengan senioritas dalam penelitian ini adalah pelaksanaan promosi jabatan eselon IV Aparatur Sipil Negara (ASN) di Badan Kepegawaian Pendidikan dan Pelatihan Kabupaten Gorontalo dengan mempertibangkan senioritas atau lama kerja seorang Aparatur Sipil Negara (ASN). Berdasarkan hasil penelitian dan analisis penulis, maka dapat diketahui bahwa pelaksanaan promosi jabatan eselon IV di Badan Kepegawaian Pendidikan dan Pelatihan Kabupaten Gorontalo berdasarkan senioritas belum menjadi syarat mutlak. Hal ini terlihat dari banyak pejabat eselon IV yang masih muda dan banyak juga pegawai yang bekerja lama tetapi belum memiliki eselon.

Keempat adalah pendidikan. Salah satu aspek yang dipertimbangkan dalam pelaksanaan promosi jabatan adalah riwayat pendidikan. Hal ini tertuang di dalam Peraturan Menteri Pendayagunaan Aparatur Negara dan Reformasi Birokrasi Nomor 13 tahun 2014 tentang tata cara pengisian jabatan pimpinan tinggi.

Sedangkan yang dimaksudkan dengan pendidikan dalam penelitian ini adalah pelaksanaan promosi jabatan eselon IV Aparatur Sipil Negara 
PUBLIK: Jurnal Manajemen Sumber Daya Manusia, Administrasi dan Pelayanan Publik Sekolah Tinggi Ilmu Administrasi Bina Taruna Gorontalo Volume VI Nomor 2 Desember 2019

(ASN) di Badan Kepegawaian Pendidikan dan Pelatihan Kabupaten Gorontalo dengan mempertibangkan aspek pendidikan. Berdasarkan hasil penelitian dan analisis penulis, maka dapat diketahui bahwa pelaksanaan promosi jabatan berdasarkan aspek pendidikan belum terpenuhi. Hal ini terlihat dari pelaksanaan promosi jabatan di lingkungan Badan Kepegawaian Pendidikan dan Pelatihan Kabupaten Gorontalo yang lebih mempertimbangkan pendidikan dari aspek jenjang ataupun kualifikasinya saja tetapi tidak mempertimbangkan dari aspek spesifikasi keilmuannya dengan bidang pekerjaan yang akan digelutinya.

Akhirnya secara keseluruhan dapat disimpulkan bahwa pelaksanaan promosi jabatan eselon IV di Badan Kepegawaian Pendidikan dan Pelatihan Kabupaten Gorontalo belum optimal. Hal tersebut dikarenakan pelaksanaan promosi jabatan eselon IV yang lebih ditentukan oleh pimpinan atau penguasa dan mengabaikan prinsip-prinsip atau persyaratan pelaksanaan promosi jabatan seperti, kemampuan, prestasi kerja, senioritas, dan pendidikan.

\section{SIMPULAN}

Berdasarkan hasil penelitian dan pembahasan pada bab sebelumnya maka selanjutnya penulis melakukan simpulan terhadap permasalahan, diantaranya;

1. Pelaksanaan promosi jabatan eselon IV di Badan Kepegawaian Pendidikan dan Pelatihan Kabupaten Gorontalo berdasarkan kemampuan belum menjadi syarat mutlak. Hal ini terlihat dari pelaksanaan promosi jabatan di Badan Kepegawaian Pendidikan dan Pelatihan Kabupaten Gorontalo yang lebih banyak ditentukan oleh faktor kedekatan dan mengabaikan aspek kemampuan.

2. Pelaksanaan promosi jabatan eselon IV di Badan Kepegawaian Pendidikan dan Pelatihan Kabupaten Gorontalo berdasarkan prestasi kerja belum menjadi syarat mutlak. Hal ini terlihat dari Daftar Penilaian Pelaksanaan Pekerjaan (DP3) pegawai yang kurang obyektif dan terdapat beberapa pegawai yang dipromosikan pada tingkat eselon IV tanpa prestasi kerja yang baik.

3. Pelaksanaan promosi jabatan eselon IV di Badan Kepegawaian Pendidikan dan Pelatihan Kabupaten Gorontalo berdasarkan senioritas belum menjadi syarat mutlak. Hal ini terlihat dari banyak pejabat eselon IV yang masih muda dan banyak juga pegawai yang bekerja lama tetapi belum memiliki eselon.

4. Pelaksanaan promosi jabatan berdasarkan aspek pendidikan belum terpenuhi. Hal ini terlihat 
PUBLIK: Jurnal Manajemen Sumber Daya Manusia, Administrasi dan Pelayanan Publik Sekolah Tinggi Ilmu Administrasi Bina Taruna Gorontalo Volume VI Nomor 2 Desember 2019

dari pelaksanaan promosi jabatan di lingkungan Badan Kepegawaian Pendidikan dan Pelatihan Kabupaten Gorontalo yang lebih mempertimbangkan pendidikan dari aspek jenjang ataupun kualifikasinya saja tetapi tidak mempertimbangkan dari aspek spesifikasi keilmuannya dengan bidang pekerjaan yang akan digelutinya.

5. Secara keseluruan dapat disimpulkan bahwa, pelaksanaan promosi jabatan eselon IV di Badan Kepegawaian Pendidikan dan Pelatihan Kabupaten Gorontalo belum optimal. Hal tersebut dikarenakan pelaksanaan promosi jabatan eselon IV yang lebih ditentukan oleh pimpinan atau penguasa dan mengabaikan prinsipprinsip atau persyaratan pelaksanaan promosi jabatan seperti, kemampuan, prestasi kerja, senioritas, dan pendidikan.

\section{SARAN}

Berdasarkan hasil penelitian dan kesimpulan di atas, maka disarankan sebagai berikut:
1. Perlunya Badan Kepegawaian Pendidikan dan Pelatihan Kabupaten Gorontalo mengedepankan aspek kemampuan dalam pelaksanaan promosi jabatan eselon IV.

2. Perlunya Badan Kepegawaian Pendidikan dan Pelatihan
Kabupaten

Gorontalo mengedepankan aspek prestasi kerja dalam pelaksanaan promosi jabatan eselon IV.

3. Perlunya Badan Kepegawaian Pendidikan dan Pelatihan Kabupaten Gorontalo mengedepankan aspek senioritas dalam pelaksanaan promosi jabatan eselon IV.

4. Perlunya Badan Kepegawaian Pendidikan dan Pelatihan Kabupaten Gorontalo mengedepankan aspek pendidikan dalam pelaksanaan promosi jabatan eselon IV.

5. Perlunya penyelenggaraan promosi jabatan eselon IV yang sesuai dengan peraturan perundangundangan yang berlaku dengan mempertimbangan, kemampuan, prestasi kerja, senioritas dan pendidikan calon pejabat.

\section{DAFTAR PUSTAKA}

Ali Faried. 2013. Teori dan Konsep Administrasi. Jakarta: PT. Raja Grafindo.

Ali Muhidin, Sambas dan Maman Abdurahman. 2009. Analisis Korelasi, Regresi, dan Jalur dalam Penelitian. Bandung : CV Pustaka Setia.

Dwiyanto, Agus.

Mengembalikan Kepercayaan

Publik Melalui Reformasi

Birokrasi. Jakarta: Gramedia Pustaka Utama. 
PUBLIK: Jurnal Manajemen Sumber Daya Manusia, Administrasi dan Pelayanan Publik Sekolah Tinggi Ilmu Administrasi Bina Taruna Gorontalo Volume VI Nomor 2 Desember 2019

Edwin. Flippo. 2008. Personel Management (Manajemen Personalia), Edisi. VII Jilid II, Terjemahan Alponso S. Jakarta: Erlangga.

Hasibuan, Malayu S. P. 2008. Manajemen Sumber Daya Manusia. Jakarta: PT. Bumi Aksara.

Hasibuan, Melayu S.P. 2013. Manajemen, Dasar, Pengertian, dan Masalah, Edisi Revisi, Cet. Keenam. Jakarta: PT.Bumi Aksara

Keban, Jeremias T. 2008. Enama dimensi Strategi Administrasi Publik, Konsep, Teori dan Isu. Yogyakarta: Gava Media.

Mangkunegara, Anwar Prabu. 2008. Manajemen Sumber Daya Manusia Perusahaan. Bandung: PT Remaja Rosdakarya.

Mangkuprawira, Sjafri. 2011. Manajemen Sumber Daya Manusia Strategik. Jakarta: Ghalia Indonesia.

Martoyo, Susilo. 2007. Manajemen Sumber Daya Manusia, Edisi 5, Cetakan Pertama. Yogyakarta: BPFE.

Marzuki. 2009. Metodologi Riset. Yogyakarta: BPFE-UII.

Mc Curdy, 2009. Paradigm Administrasi Publik. Cetakan 7. Jakarta: Pustaka Binaman Pressindo.

Nawawi Hadari. 2011. Manajemen Sumber Daya Manusia. Cetakan
Pertama. Yogyakarta: Gajah Mada University Press.

Nur Indriantoro dan Bambang Supomo. 2009. Metodologi Penelitian Bisnis. Yogyakarta: BPFE.

Pratikno. 2008. Manajemen Jaringan dalam Perspektif Stukturasi, Jurnal Kebijakan dan Administrasi Publik, Mei 2008, Volume 12 Nomor 1. Yogyakarta: MAP UGM.

Rachmawati, Nina 2008. Manajemen Pelayanan Prima. Yogyakarta: Graha Ilmu

Silalahi, Ulbert. 2009. Studi Tentang Ilmu Administrasi: Konsep, Teori dan Dimensi. Bandung: Sinar Baru Algesindo

Simamora, Henry. 2009. Manajemen Sumber Daya Manusia. Edisi ke2. Cetakan Kedua, Yogyakarta: STIE YKPN.

Sondang P. Siagian. 2008. Organisasi, Kepemimpinan dan Perilaku Administrasi. Jakarta: Gunung Agung.

Sondang P. Siagian. 2009. Kiat Meningkatkan Produktifitas Kerja. Jakarta. PT Rineka Cipta.

Sugiyono, 2013. Metode Penelitian Bisnis. Bandung: Alfabeta.

Syafeiie, Inu Kencana. 2003. Manajemen Pemerintahan. Jakarta: PT. Pertja.

Thoha, Miftah.2007. Ilmu Administrasi Publik Kontemporer. Jakarta: Kencana 
PUBLIK: Jurnal Manajemen Sumber Daya Manusia, Administrasi dan Pelayanan Publik Sekolah Tinggi Ilmu Administrasi Bina Taruna Gorontalo Volume VI Nomor 2 Desember 2019

Utomo. 2007. Dinamika Administrasi Publik. Yogyakarta: Pustaka Pelajar.

Wilson. 2009. Manajemen Sumber

Daya Manusia. Jakarta:

Erlangga. 